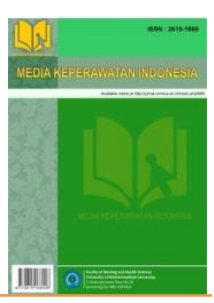

Research article

\title{
Combination of Deep Breathing Relaxation and Murottal Reducing Post Chemotherapy Nausea Intensity in Nasopharyngeal Cancer (NPC) Patients
}

\author{
Agus Suryono ${ }^{1}$, Fakhruddin Akbar ${ }^{2}$, Fredi Setia Nugraha ${ }^{3}$, Yunie Armiyati ${ }^{4}$ \\ 1,2,3 RSUP Dr. Kariadi Semarang \\ ${ }^{4}$ Nursing Department, Universitas Muhammadiyah Semarang
}

\section{Article Info}

Article History:

Accepted 26 February 2020

\section{Keywords:}

Deep Breathing Relaxation;

Murottal; Nausea;

Nasopharyngeal Cancer

Abstract
Nasopharyngeal Cancer (NPC) is the 3rd most common type of cancer in
Indonesia after cervical and breast cancer. The method for controlling the
growth of cancer cells is chemotherapy which has side effects of nausea.
Post-chemotherapy nausea makes the patient uncomfortable and if not
treated properly will cause complications. Management of nausea can be
done with a combination of deep breathing relaxation and murottal. The
objective of the study to analyze the effect of a combination of deep
breathing relaxation and murottal on the intensity of nausea in NPC patients
after chemotherapy. The research method was a quasi-experiment one
group pre-post-test design on 30 samples of post-chemotherapy NPC
patients. The results of the study showed that nausea intensity before and
after given a combination of deep breathing and murottal obtained p-value
0,000 (p-value <0.05). There is a significant difference between nausea
intensity before and after the combination of deep breathing and murottal
relaxation. The combination of deep breathing and murottal breathing can
reduce the intensity of nausea in NPC patients after chemotherapy.

Metode yang dapat digunakan untuk mengendalikan pertumbuhan sel kanker antara lain dengan kemoterapi. Kemoterapi merupakan pemberian pemberian obat dengan tujuan untuk membunuh sel-sel kanker (Rasjidi, 2007). Kemoterapi merupakan terapi sistemik, yang berarti bahwa obat menyebar ke seluruh tubuh dan dapat mencapai sel kanker yang telah menyebar jauh sehingga juga memiliki efek samping yang merugikan. Efek samping yang paling sering terjadi pasca kemoterapi adalah mielosupresi, mual, dan muntah. Mual dan muntah merupakan efek samping dari pemberian obat sitostatika yang paling 
membuat pasien tidak nyaman. Mual muntah akut terjadi dalam waktu 24 jam pertama pasca pemberian obat sitostatika yang dimulai 1 sampai 2 jam setelah pemberian obat sitostatika. Kejadian ini akan berakhir setelah 24 jam (Sari, Hartoyo, $\&$ Wulandari, 2015).

Mual dan muntah pasca kemoterapi perlu mendapatkan perhatian karena dapat menyebabkan stres bagi penderita dan keluarga yang terkadang membuat penderita dan keluarga memilih menghentikan siklus terapi. Ketidaknyamanan akibat mual muntah paska kemoterapi dapat berpengaruh pada respon emosional pasien (timbul stres dan kecemasan) yang dapat memperburuk intensitas mual, retching, dan muntah. Mual muntah yang tidak ditangani dengan baik juga akan menyebabkan timbulnya dehidrasi, ketidakseimbangan elektrolit, dan risiko terjadinya aspirasi pneumonia. Efek mual muntah juga akan berdampak pada perubahan status fungsional pasien yang menjalani program kemoterapi. Penanganan mual dan muntah dapat dilakukan secara farmakaologis dan nonfarmakologis.

Beberapa manajemen nonfarmakologis yang dapat digunakan untuk mengurangi mual antara lain biofeed back, hiponosis, relaksasi, imajinasi terbimbing, terapi musik, distraksi, dan akupresur (Butcher, Bulechek, Dochterman, \& Wagner, 2018). Chemotherapy induced nausea and vomiting (CINV) melalui pendekatan kompehensif meliputi pemberian anti emetik, suplementasi herbal, metode akupunktur, dan intervensi biopsychobehavioral. Intervensi biopsychobehavioral untuk menurunkan intensitas mual pasca kemoterapi dapat dilakukan dengan membuat pasien menjadi rileks (Nindya, S. R., Bakti, 2016). Intervensi ini dapat dilakukan mandiri oleh perawat.

Intervensi biopsychobehavioral untuk membuat pasien pasca kemoterapi menjadi rileks dapat dilakukan dengan metode relaksasi napas dalam yang dikombinasikan aspek religi dengan mendengarkan murottal Al Qur'an. Relaksasi napas dalam merupakan pernapasan pada abdomen dengan frekuensi lambat serta perlahan, berirama, dan nyaman dengan cara memejamkan mata saat menarik napas. Efek dari teknik relaksasi ini adalah distraksi atau pengalihan perhatian (Rahayuningrum, 2016). Teknik relaksasi napas dalam juga dapat menurunkan intensitas mual, menurunkan kecemasan dan meningkatkan oksigenisasi darah (Siswantinah, 2011). Studi randomized controlled trial pada pasien post operasi menunjukkan bahwa pernapasan terkontrol efektif menurunkan gejala mual dan muntah paska operasi sebesar $62,5 \%$ (Sites et al., 2014).

Mendengarkan murottal Al Qur'an juga akan meningkatkan relaksasi pasien. Mendengarkan murottal selamat 25 menit dapat meningkatkan kadar endorfin pada pasien yang membuat pasien menjadi rileks. Penelitian sebelumnya menunjukkan murottal yang diperdengarkan dengan frekuensi $60 \mathrm{~dB}$ dapat membuat pasien menjadi nyaman (Sukron, 2018). Mendengarkan murottal juga membuat seseorang akan lebih dekat dengan Tuhan serta menuntun subjek untuk mengingat dan menyerahkan segala permasalahan yang dimiliki kepada Tuhan (Rahman, Mohdari, \& Prasetyo, 2017). Hal ini akan membuat subjek yang mendengarkan murottal menjadi lebih nyaman dan rileks, sehingga mual pasien menjadi berkurang (Abdurrachman \& Andhika S, 2008).

Relaksasi napas dalam yang dikombinasikan dengan mendengarkan murottal akan menguatkan efek relaksasi, meningkatkan rasa nyaman dan memberikan efek yang lebih baik pada rasa mual pasien. Penelitian ini perlu dilakukan untuk mengembangkan intervensi nonfarmakologi dalam mengatasi mual muntah pasca kemoterapi dengan melihat pengaruh kombinasi relaksasi napas dalam dan murottal terhadap intensitas mual pada 
pasien KNF pasca kemoterapi. Tujuan penelitian ini untuk menganalisis pengaruh kombinasi relaksasi napas dalam dan murottal dalam menginduksi relaksasi dan menurunkan intensitas mual pasca kemoterapi pada pasien KNF.

\section{METODE}

Penelitian ini adalah penelitian quasiexperimental one group pre-post test desain yang meneliti tentang pengaruh kombinasi relaksasi napas dalam dan murottal terhadap intensitas mual pasien KNF pasca kemoterapi. Penelitian dilakukan di Ruang Kasuari lt 3 dan lt 5, Instalasi Kasuari RSUP. Dr. Kariadi Semarang pada 1 Juli 2019 sampai 30 November 2019.

Subjek penelitian terdiri dari 30 pasien yang diperoleh melalui teknik purposive sampling, sesuai kriteria inklusi yaitu; pasien KNF pasca kemoterapi dengan intensitas mual 6 sampai 10, beragama Islam, sadar dan dapat berkomunikasi, tidak ada gangguan pendengaran, dapat menerima intervensi pada jam ke-7 sesudah mendapatkan obat anti-emesis. Kriteria eksklusi pasien tidak mampu lagi melanjutkan penelitian karena timbul komplikasi kemoterapi seperti sesak napas, kesakitan hebat.

Instrumen yang digunakan dalam penelitian ini adalah instrument pengukur intensitas mual dengan Numeric Rating Scale (NRS) dengan skala pengukuran dalam rentang 0-10. Nilai 0 diberi kategori "tidak mual sama sekali" dan nilai 10 diberi kategori "sangat mual sekali". NRS telah digunakan oleh banyak peneliti sebelumnya untuk mengukur intensitas mual. Peralatan lain dalam penelitian ini adalah MP3 surat Ar-Rahman yang dilantunkan oleh Muzammil Hasballah yang diputar menggunakan Speaker box music dan didengarkan melalui Headset.

Prosedur pengambilan data penelitian sebagai berikut: a) Menentukan responden sesuai dengan kriteria inklusi, b)
Memberikan informed consent pada calon responden. c) Setelah calon responden setuju untuk menjadi responden, peneliti kontrak waktu untuk melakukan penelitian. d) Mengukur intensitas mual responden dengan instrumen Numeric Rating Scale (NRS) dan mencatat hasil ukur di kolom intensitas mual sebelum diberikan intervensi. d) Peneliti memberikan intervensi pada responden yaitu: meminta pasien untuk memejamkan mata kemudian menarik napas panjang lewat hidung lalu menghembuskannya pelan lewat mulut dengan fase menghembuskan napas 2 kali lebih lama daripada fase menarik napas. Pasien diminta melakukan relaksasi napas dalam sebanyak 3 kali yang dilanjutkan dengan mendengarkan murotal surat ArRahman yang diputar menggunakan speaker box music dan didengarkan denga headset selama 25 menit. e) Mengukur kembali intensitas mual dengan instrumen NRS pada responden setelah intervensi. f) Mencatat hasil pengukuran di kolom intensitas mual sesudah intervensi.

Analisis univariat digunakan untuk mendeskripsikan data karakteristik responden berupa umur, jenis kelamin, pendidikan, pekerjaan, frekwensi kemoterapi, dan intensitas mual. Analisis bivariat dilakukan dengan menggunakan soft ware pengolahan data statistik yang ada di komputer. Analisis bivariat diawali dengan melakukan uji normalitas data. Uji pengaruh kombinasi relaksasi napas dalam dan murottal terhadap intensitas mual menggunakan uji Wilcoxon karena kedua variabel berdistribusi tidak normal.

Penelitian dilakukan setelah mendapatkan persetujuan dari komite etik penelitian kesehatan RSUP. Dr. Kariadi Semarang dengan nomor 261/EC/KEPK-RSDK/2019. Peneliti memperhatikan etika penelitian meliputi prinsip kerahasiaan, manfaat, prinsip menghormati hak asasi manusia (menghormati martabat manusia) dan prinsip keadilan. 


\section{HASIL}

Hasil penelitian menunjukan bahwa umur rata-rata responden penderita KNF adalah 50,77 tahun dengan pengalaman kemoterapi rata-rata adalah 2,57 kali. Sebagian besar $(63,3 \%)$ responden berjenis kelamin laki-laki dengan tingkat pendidikan terbanyak $(46,7 \%)$ adalah SD. Frekwensi kemoterapi responden rata-rata adalah 2,57 kali dengan rentang paling sedikit 1 kali dan paling banyak 6 kali menjalani program kemoterapi.

Tabel 1

Karakteristik Responden Pasien KNF di RSUP. Dr. Kariadi Semarang $(n=30)$

\begin{tabular}{|c|c|c|}
\hline Indikator & $f(\%)$ & Mean \pm SD \\
\hline Usia (tahun) & & $50,77 \pm 10,814$ \\
\hline Frekwensi & & $2,57 \pm 1,755$ \\
\hline kemoterapi (kali) & & \\
\hline Pendidikan & & \\
\hline a. SD & $1(8,3 \%)$ & \\
\hline b.SMP & $2(16,7 \%)$ & \\
\hline c. SMA & $6(50 \%)$ & \\
\hline d.PT & $3(25 \%)$ & \\
\hline
\end{tabular}

Hasil uji homogenitas karakteristik responden (usia, jenis kelamin, frekwensi kemoterapi dan tingkat pendidikan) pasien KNF di RSUP. Dr. Kariadi Semarang berdasarkan rasa mual post kemoterapi menunjukkan $p$ value 0,$937 ; 0,415 ; 0,527$ dan 0,457 ( $\mathrm{p}$ value $>0,005$ ). Hasil tersebut menujukkan variabel karakteristik responden adalah homogen. Intensitas mual pasien pasca kemoterapi memiliki variasi yang sama pada semua karakteristik respoden.

Hasil penelitian menunjukan bahwa intensitas mual pasien KNF pasca kemoterapi sebelum diberikan intervensi keperawatan kombinasai relaksasi napas dalam dan murottal rata-rata sebesar 7,33. Intensitas mual pasien KNF pasca kemoterapi setelah diberikan kombinasai relaksasi napas dalam dan murottal surat Ar-Rahman rata-rata sebesar 5. Analisis pengaruh kombinasi relaksasi napas dalam dan murottal dilakukan dengan uji Wilcoxon hasilnya didapatkan $p$ value 0,000 , menunjukkan bahwa kombinasi relaksasi napas dalam dan murottal surat Ar-Rahman efektif untuk menurunkan intensitas mual pasien KNF pasca kemoterapi.

Tabel 2

Intensitas Mual Pasca Kemoterapi Pasien KNF di RSUP. Dr. Kariadi Semarang $(n=30)$

\begin{tabular}{ccc}
\hline Intensitas mual & Mean \pm SD & $\mathrm{p}$ \\
\hline Sebelum intervensi & $7,33 \pm 1,093$ & $0,000^{*}$ \\
Sesudah intervensi & $5 \pm 0,947$ & \\
\hline
\end{tabular}

*) uji wilcoxon

\section{PEMBAHASAN}

Mual merupakan kecenderungan untuk muntah atau sebagai perasaan di tenggorokan atau daerah epigastrium yang memperingatkan seorang individu bahwa muntah akan segera terjadi. Mual sering disertai dengan peningkatan aktivitas sistem saraf parasimpatis termasuk diaphoresis, air liur, bradikardia, pucat dan penurunan tingkat pernapasan (Eskandari, Keshavars, Ashayeri, Jahdi, \& Hosseini, 2012). Obat sitostatika yang diberikan pada pasien kemoterapi dapat menimbulkan efek mual dan muntah melaui beberapa mekanisme yaitu pusat muntah, chemoreceptor trigger zone (CTZ), saraf aferen vagus yang berasal dari gastrointestinal menuju postrema. CTZ sangat sensitif terhadap stimulus kimia. Obat sitostatika merupakan stimulus kimia yang akan mengaktifkan saraf aferen vagus dan menghasilkan input sensori yang akan mengaktifkan otot perut, diafragma, lambung, dan esophagus untuk menimbulkan muntah (Perwitasari, 2008). Mual juga dapat di rangsang oleh beberapa stimulus seperti penyakit, nyeri hebat, juga status emosional yang kuat (Stanfield, 2014). Intensitas mual muntah paska kemoterapi dapat bertambah dengan adanya stres dan status emosi yang kurang baik. Ketidaknyamanan akibat mual muntah paska kemoterapi dapat berpengaruh pada respon emosional pasien yang dapat semakin memperburuk intensitas mual dan muntah pasien. 
Penelitian ini bertujuan untuk melihat pengaruh kombinasi relaksasi napas dalam dan murrotal Al-Qur'an dalam menurunkan intensitas mual paska kemoterapi melalui jalur penurunan stres dan peningkatan relaksasi. Mual dan muntah pada penelitian ini diatasi dengan kombinasi relaksasi napas dalam dan murottal. Teknik ini termasuk dalam kategori intervensi biopsychobehavioral. Kombinasi relaksasi napas dalam dan murottal merupakan penggabungan antara metode relaksasi napas dalam yang dilakukan sebanyak 3 kali dan mendengarkan murottal surat ArRahman selama 25 menit. Teknik ini digunakan untuk membuat pasien berada dalam kondisi relaks secara fisik dan mental sehingga efek mual dan muntah pasca kemoterapi dapat ditekan. Teknik ini dapat mengurangi mual dan muntah pada empat hari pertama pasca kemoterapi (Nindya, S. R., Bakti, 2016).

Hasil penelitian menunjukkan rata-rata intensitas rasa mual sebelum diberikan intervensi kombinasi relaksasi napas dalam dan murottal adalah 7,33 (mual berat) dan sesudah diberikan intervensi kombinasi relaksasi napas dalam dan murottal surat Ar-Rahman turun menjadi 5 (mual sedang). Penelitian ini menunjukkan ada perbedaan yang signifikan antara skor rasa mual sebelum dan sesudah diberikan kombinasi relaksasi napas dalam dan murottal. Ratarata penurunan intensitas mual responden diberikan intervensi kombinasi relaksasi napas dalam dan murottal adalah 2,33 $(31,79 \%)$.

Kombinasi relaksasi napas dalam dan murottal merupakan terapi non farmakologi yang dapat digunakan mengurangi rasa mual melalui jalur penurunan stres dan peningkatan relaksasi. Metode ini merupakan penggabungan antara metode relaksasi napas dalam dan terapi religi mendengarkan murottal surat Ar-Rahman selama 25 menit. Teknik relaksasi napas dalam merupakan suatu bentuk asuhan keperawatan, yang dalam hal ini perawat mengajarkan kepada klien bagaimana cara melakukan napas dalam, napas lambat (menahan inspirasi secara maksimal) dan bagaimana menghembuskan napas secara perlahan. Teknik relaksasi napas dalam dapat menurunkan intensitas mual, meningkatkan ventilisasi paru, menurunkan kecemasan dan meningkatkan oksigenisasi darah (Siswantinah, 2011). Penelitian RCT pada pasien post operasi menunjukkan pernapasan terkontrol lebih efektif menurunkan gejala mual dan muntah paska operasi sebesar 62,5\% dibanding menggunakan aromaterapi peppermint yang mampu menurunkan gejala mual munta sebesar $57,7 \%$ (Sites et al., 2014).

Penelitian sebelumnya menguatkan temuan penelitian ini bahwa efek relaksasi meningkat setelah diberikan kombinasi relaksasi napas dalam dan murottal. Penelitian kombinasi relaksasi napas dalam dan murottal Surat Ar-Rahman juga terbukti menurunkan kadar gula darah sewaktu pada pasien Diabetes karena adanya efek relaksasi. Efek relaksasi ditunjukkan dengan perubahan hemodinamik yang menunjukkan adanya perubahan hemodinamik (tekanan darah dan nadi) yang cenderung menurun setelah diberikan intervensi. Penelitian sebelumnya menunjukkan bahwa kombinasi relaksasi napas dalam dan murottal lebih efektif menurunkan kadar gula darah sewaktu sebesar 23,93\%, sementara kelompok relaksasi napas gula darah sewaktu dalam turun sebesar 9,97\% dan kelompok murottal turun sebesar 2,56\% (Armiyati, 2019).

Bacaan al-Qur'an secara murottal dipilih dalam penelitian ini karena mempunyai irama yang konstan, teratur dan tidak ada perubahan yang mendadak. Tempo murottal al-Qur'an juga berada antara 60$70 /$ menit, serta nadanya rendah sehingga mempunyai efek relaksasi dan dapat menurunkan stress dan kecemasan (Yueniwati, 2016). Penelitian ini menggunakan Murottal surat Ar-Rahman 
karena surah tersebut mengandung hikmah besar bagi kemanusiaan pada umumnya dan bagi umat Islam pada khususnya. Ini terkait dengan tingkat syukur dalam arti luas dari arti ketidaktaatan pemberi (Allah SWT). Surah Arrahman didahului dengan pernyataan tentang sifat Allah, Allah Yang Maha Pemurah. Kemurahan hatinya adalah sumber dari semua pemberian yang diberikan kepada seluruh umat manusia (Darmadi \& Armiyati, 2019).

Studi lain juga mendukung temuan penelitian ini. Penelitian pada pre kateterisasi jantung di RSUP Dr. Kariadi menunjukkan bahwa terapi Murottal dapat mengurangi skor kecemasan sebesar 42,8\% sementara terapi musik klasik dapat mengurangi skor kecemasan pada pasien kateterisasi jantung sebesar 23,6\%. Penurunan kecemasan terjadi karena terapi murottal yang diberikan lebih dimengerti oleh responden (Darmadi \& Armiyati, 2019).

Rangsangan yang diberikan pada auditori murottal juga memiliki dampak dari distraksi yaitu peningkatan pembentukan hormon endorphine pada sistem kontrol desenden. Kenaikan pada total hormon endorphine akan murottal akan menstimulasi hipotalamus yang berguna untuk memproduksi neuropeptida, neuropeptida nantinya akan mempunyai dampak bagi tubuh yaitu kenyamanan diperoleh melalui penurunan jumlah hormon kortisol, epineprin, norepineprin, dan dopamin. Efek ini juga dibuktikan bahwa terapi Murottal surat Al-Kahfi dapat menurunkan tekanan darah pada 20 pasien hipertensi di di Wilayah Kerja Puskesmas Bandarharjo Semarang (Irmachatshalihah \& Armiyati, 2019).

Terapi murottal berupa melantunkan ayat Al-Qur'an dari surat Ar-Rahman dapat dirasakan menyejukkan hati, menenangkan dan semakin dekat dengan Tuhan sehingga pasien lebih rileks dan mengurangi tingkat kecemasan. Al-Qur'an memiliki pengaruh besar pada jiwa seseorang. mendengarkan
Al-Qur'an akan memberi efek kedamaian dalam tubuh karena unsur-unsur meditasi dan relaksasi. Perasaan tenang ini kemudian akan memberikan respons emosional positif yang sangat berpengaruh dalam mewujudkan persepsi positif.

Memperdengarkan terapi murottal pada seseorang maka kualitas kesadaran seseorang terhadap Tuhan akan meningkat, baik orang tersebut tahu arti al-Qur'an atau tidak. Kesadaran ini akan menyebabkan totalitas kepasrahan kepada Allah SWT. Kepasrahan yang ada dalam diri seseorang berarti otak ada pada gelombang alpha, yang merupakan gelombang otak pada frekuensi 7-14 Hz. Ini merupakan keadaan energi otak yang optimal dan dapat menyingkirkan stres dan menurunkan kecemasan, sehingga mual yang ditimbulkan karena pemberian obat sitostatika dapat berkurang (Hesketh, 2008). Rasa tenang saat mendengarkan murottal akan memberikan respon emosi positif yang sangat berpengaruh dalam mendatangkan persepsi positif. Riset sebelumnya juga menunjukkan pemberian terapi murottal $\mathrm{Al}$ Qur'an mampu menurunkan tingkat stres dan depresi pasien yang menjalani hemodialisis (Rahayu, Hidayati, \& Imam, 2018)

Temuan penelitian ini juga menguatkan studi sebelumnya tentang "Pengaruh musik dan imagery dalam menginduksi relaksasi dan mengurangi mual dan emesis pada pasien dengan kanker yang sedang menjalani kemoterapi" yang juga menunjukkan hasil positif adanya penurunan signifikan dalam frekuensi mual dan emesis dari waktu ke waktu setelah diberikan musik yang dikombinasikan dengan imagery selama 6 minggu pengobatan. Efek relaksasi mendengarkan musik dan imagery mampu meningkatkan relaksasi dengan menurunkan heart rate dan rasa mual lebih besar dibanding hanya dengan imagery saja (Montserrat Gimeno, 2010). 
Hasil studi ini menunjukkan bahwa intervensi sederhana dengan realaksasi napas dalam dan mendengarkan murottal dengan biaya yang relatif efektif dapat mengurangi mual pasca kemoterapi pada pasien dengan kanker. Kombinasi relaksasi napas dalam dan mendengarkan murottal mampu meningkatkan kemampuan adaptasi yang mendapatkan kemoterai yang ditunjukkan dengan adanya potensi dalam mengurangi tingkat stres, meningkatkan relaksasi, dan mengurangi mual muntah. Temuan penelitian dapat bermanfaat untuk meningkatkan kualitas hidup pada pasien KNF yang menjalani kemoterapi.

Keterbatasan penelitian ini adalah banyak variabel yang terlibat dan belum adanya kelompok kontrol. Peneliti selanjutnya dapat mengembangkan intervensi pada kelompok pasien kanker jenis lain dengan menambahkan kelompok kontrol dan memberikan perlakukan secara berseri selam 48-72 jam paska kemoterapi.

\section{SIMPULAN}

Ada perbedaan yang signifikan antara intensitas rasa mual sebelum dan sesudah diberikan kombinasi relaksasi napas dalam dan murottal. Kombinasi relaksasi napas dalam dan murottal dapat meningkatkan efek relaksasi, menurunkan stres dan menurunkan intensitas mual paska kemoterapi pada pasien KNF.

\section{UCAPAN TERIMAKASIH}

Ucapan terimakasih kami sampaikan kepada Direktur Utama RSUP Dr. Kariadi Semarang yang telah memberikan ijin dan pembiayaan dalam penelitian ini. Terimakasih juga kepada responden penelitian yang berpartisipasi dalam studi ini.

\section{REFERENSI}

Abdurrachman \& Andhika S. (2008). Murottal AlQur'an: Alternatif terapi suara baru. Seminar Nasional Sains Dan Teknologi-II. Lampung:
Universitas Lampung;

Adham, M., Kurniawan, A. N., Muhtadi, A. I., Roezin, A., Hermani, B., Gondhowiardjo, S., ... Middeldorp, J. M. (2012). Nasopharyngeal carcinoma in Indonesia: epidemiology, incidence, signs, and symptoms at presentation. Chinese Journal of Cancer.

Armiyati, Y. (2019). Kombinasi relaksasi nafas dalam dan Murottal Surah Ar-Rahman menurunkan Gula Darah Sewaktu pada p asien DM Tipe II The combination of deep breathing relaxation and Murottal Surah Ar-Rahman decrease blood glucose. In Prosiding Seminar Nasional Mahasiswa Unimus (Vol. 2).

Butcher, H. K., Bulechek, G. M., Dochterman, J. M. M., \& Wagner, C. M. (2018). Nursing Interventions Classification (NIC). In Elsevier.

Darmadi, S., \& Armiyati, Y. (2019). Murottal and clasical music therapy reducing pra cardiac chateterization anxiety. South East Asia Nursing Research, 1(2), 52. https://doi.org/10.26714/seanr.1.2.2019.5260

Eskandari, N., Keshavars, M., Ashayeri, H., Jahdi, F., \& Hosseini, A. F. (2012). Quran recitation: shortterm effect and related factors in preterm newborns. Research Journal of Medical Sciencences, 6, 148-153.

Hesketh, P. J. (2008). Chemotherapy-induced nausea \& vomiting. The New England Journal of Medicine, 358, 2482-2494. https://doi.org/DOI: NEJMra0706547.

Irmachatshalihah, R., \& Armiyati, Y. (2019). Murottal Therapy Lowers Blood Pressure in Hypertensive Patients. Media Keperawatan Indonesia, 2(3), 97. https://doi.org/10.26714/mki.2.3.2019.97104

Montserrat Gimeno, M. (2010). The effect of music and imagery to induce relaxation and reduce nausea and emesis in patients with cancer undergoing chemotherapy treatment. Music and

Medicine. https://doi.org/10.1177/1943862110374622

Nindya, S. R., Bakti, S. (2016). Terapi mual muntah pasca Kemoterapi. Jurnal THT - KL, 9, 74-83.

Perwitasari. (2008). Telaah pustaka farmakoogenetik antiemetik antagonis reseptor 5-hidroksitriptamin 3 dalam onkologi. Universitas Ahmad Dahlan. 
Rahayu, D. A., Hidayati, T. N., \& Imam, T. A. (2018). The effect of murottal therapy in decreasing depression of patients undergoing hemodialysis. Media Keperawatan Indonesia, $1(2)$, https://doi.org/10.26714/mki.1.2.2018.6-10

Rahayuningrum, D. C. (2016). Perbedaan pengaruh teknik relaksasi nafas dalam dan kompres hangat dalam menurunkan dismenore pada remaja SMA Negeri 3 Padang. Jurnal Medika Saintika, 7.

Rahman, T. A., Mohdari, M., \& Prasetyo, A. (2017). Murottal therapy to anxiety levels of patients pre-operative at Sari Mulia Hospital Banjarmasin. Advances in Health Science Research, 6.

Rasjidi, I. (2007). Kemoterapi kanker ginekologi dalam praktek sehari-hari. Jakarta: CV Sagung Seto.

Sari, R. I., Hartoyo, M., \& Wulandari. (2015). Pengaruh aromaterapi pappermint terhadap penurunan mual muntah akut pada pasien yang menjalani kemoterapi di SMC RS Telogorejo. Ejournal Stikes Telogorejo.

Siswantinah. (2011). Pengaruh terapi murottal terhadap kecemasan pasien Gagal Ginjal Kronik yang dilakukan tindakan hemodialisa di RSUD Kraton Kabupaten Pekalongan. Jurnal Universitas Muhammadiyah Semarang.

Sites, D. S., Johnson, N. T., Miller, J. A., Torbush, P. H., Hardin, J. S., Knowles, S. S., ... Tart, R. C. (2014). Controlled breathing with or without peppermint aromatherapy for postoperative nausea and/or vomiting symptom relief: A randomized controlled trial. Journal of Perianesthesia Nursing, 29(1), 12-19. https://doi.org/10.1016/j.jopan.2013.09.008

Stanfield, C. L. (2014). Principles of human physiology. Pearson Education Limited.

Sukron. (2018). Perbedaan efektivitas terapi musik klasik dan terapi murotal terhadap tingkat kecemasan pasien pre operasi bedah mayor. Jurnal Ilmiah Multi Science Kesehatan, 9.

Yueniwati, Y. (2016). Tumor extension and tumor staging of Nasopharyngeal Carcinoma. Proceeding Book: Indonesian Society of Radiology, ASM XI. Kalimantan Timur. 